\title{
Development of model systems for $\beta$-thalassaemia
}

\section{Jim Vadolas}

Murdoch Childrens Research Institute, Royal Children's Hospital, Australia

\section{Oral presentation}

Oral presentation is available online

\begin{abstract}
Correspondence: Jim Vadolas
(C) Copyright J. Vadolas, 2013

Licensee PAGEPress, Italy

Thalassemia Reports 2013; 3(s1):e41

doi:10.4081/thal.2013.s1.e41

This article is distributed under the terms of the Creative Commons Attribution Noncommercial License (by-nc 3.0) which permits any noncommercial use, distribution, and reproduction in any medium, provided the original author(s) and source are credited.

Parts of this work were presented at the

"3rd Pan-European Conference on Haemoglobinopathies and Rare Anaemias", Limassol (Cyprus), 24-26 October 2012.
\end{abstract}

